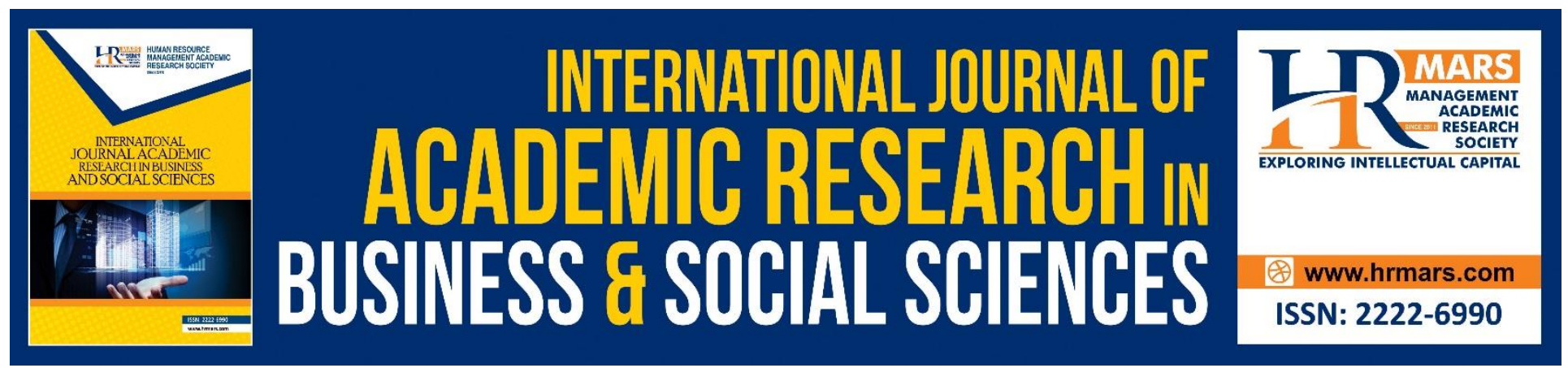

\title{
Parents' Motivation and Experience on Business Performance: The Mediating Effect of Financial Literacy Among SMEs in Sumatera, Indonesia
}

Rika Desiyanti, Aza Azlina Md Kassim

To Link this Article: http://dx.doi.org/10.6007/IJARBSS/v10-i7/7402

DOI:10.6007/IJARBSS/v10-i7/7402

Received: 08 April 2020, Revised: 13 May 2020, Accepted: 29 June 2020

Published Online: 24 July 2020

In-Text Citation: (Desiyanti \& Kassim, 2020)

To Cite this Article: Desiyanti, R., \& Kassim, A. A. M. (2020). Parents' Motivation and Experience on Business Performance: The Mediating Effect of Financial Literacy Among SMEs in Sumatera, Indonesia. International Journal of Academic Research in Business and Social Sciences, 10(7), 150-170.

Copyright: (C) 2020 The Author(s)

Published by Human Resource Management Academic Research Society (www.hrmars.com)

This article is published under the Creative Commons Attribution (CC BY 4.0) license. Anyone may reproduce, distribute, translate and create derivative works of this article (for both commercial and non-commercial purposes), subject to full attribution to the original publication and authors. The full terms of this license may be seen

at: http://creativecommons.org/licences/by/4.0/legalcode

Vol. 10, No. 7, 2020, Pg. 150 - 170

http://hrmars.com/index.php/pages/detail/IJARBSS

JOURNAL HOMEPAGE

Full Terms \& Conditions of access and use can be found at http://hrmars.com/index.php/pages/detail/publication-ethics 


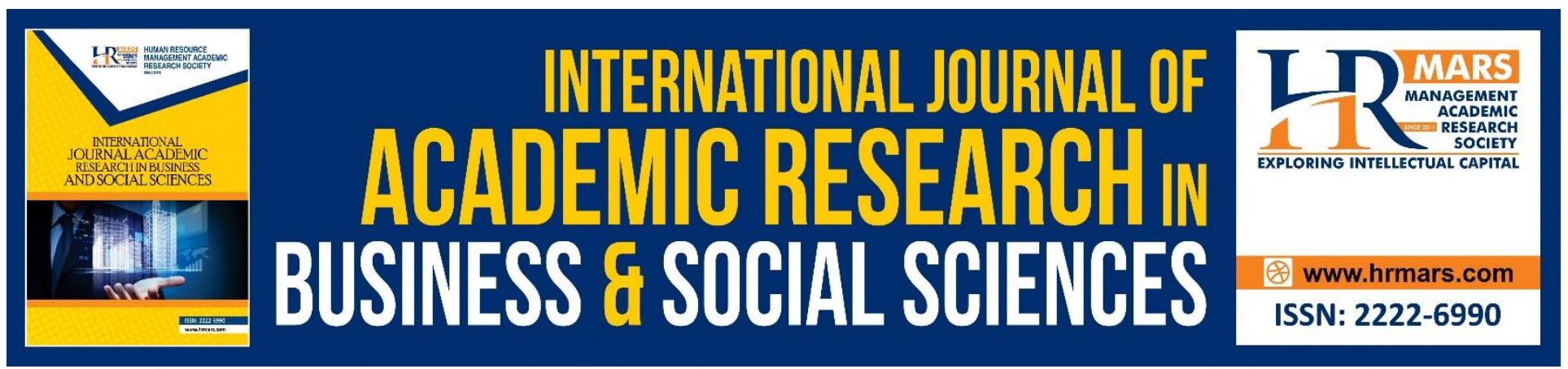

\title{
Parents' Motivation and Experience on Business Performance: The Mediating Effect of Financial Literacy Among SMEs in Sumatera, Indonesia
}

\author{
Rika Desiyanti, Aza Azlina Md Kassim \\ Faculty of Economics and Business Bung Hatta University, Faculty of Business and Accountancy, \\ Universiti Selangor \\ Email: rikadesiyanti@bunghatta.ac.id, aza_azlina@unisel.edu.my
}

\begin{abstract}
Business performance is an achievement as the result achieved by individuals work and a company. In the years between 2012 and 2014 the Enterprise Survey (2015) has conducted a financial survey of Indonesian private sector/micro which experienced negative real annual sale growth $(-0.5 \%)$, while the average in lowermiddle-income economies was $0.6 \%$. Small firms (5-19 employees) had the worst performance. The owners of SMEs should manage their financial business effectively to achieve good business performances. Low level of financial literacy causes bad effect on business performances. This paper aims to analyze the influence of parents' motivation and experience on SME's business performance with financial literacy as the mediating variable. Questionnaire survey has been distributed among SMEs owners in Sumatera, Indonesia. From 387 respondents as the sample of this study, the result shows that parents' motivation does affect the financial literacy. Nevertheless, parents' financial experience has no effect on SME's owners' financial literacy. Besides, parents' motivation and experience affect the business performance. However, financial literacy does not mediate the relationship between parents' motivation and parent's experience towards business performance.
\end{abstract}

Keywords: Parents' Motivation, Parents' Experience, Financial Literacy, Business Performance.

\section{Introduction}

Business performance is an important criterion for business owners in reaching their business targets. A strong foundation and performance of business will give positive effect on the economic sustainability of a country. Good business performance will generally enhance business development. The ability to manage business financial by the owners (financial literacy) is indeed very necessary for business performances and their continuity. Increasing financial literacy of business owners or SME's owners will lead to healthy business financial decisions. It seems that the owners of SMEs are more likely to manage business financial matters effectively.

Owner's low levels of financial literacy might lead to unprofitable investment, bad business performance, and bankruptcy. Therefore, it is very important to examine the influence of SMEs 
owners' financing literacy on their business performance. Financial literacy is the knowledge and ability in organizing financial matters in both personal and business levels. Desiyanti (2016) has studied the financial literacy as well as utility index SMEs in Padang City. The result shows that financial literacy is needed in the business. Anggraeni (2015) posits that the ability to manage the finances of the business is fundamental in enhancing business performance. SME's owners need sufficient financial literacy to manage their business, which may be derived from several sources, in order to support the maintenance and progress of their business. Financial literacy was one of the major factors associated with the SME's business performance.

According to the Enterprise Survey (2015), in the years between 2012 and 2014, Indonesian private sectors experienced negative real annual sale growth $(-0.5 \%)$, while the average in lower-middleincome economies was $0.6 \%$. Small firms (5-19 employees) had the worst performance, with negative annual sales growth (-1.4\%), while sales for large firms (100 or more employees) grew by $1.1 \%$ annually. Medium firms (20-99 employees) were the best performers with an annual sales growth of $3.6 \%$. In the same period, the annual employment growth rate for Indonesia was only $0.5 \%$, well below the average for lower-middle countries (4.5\%).

Motivation and experience from parents are indispensable in supporting and financing their children's education. Parents play an important role in their children's financial education. They must build the financial independence of their children (Campenhout, 2015). Through disseminating of norms on finance, teaching financial concepts and by giving their child the opportunity to handle and manage their own money. These will affect good financial decision making and financial literacy. Norvilitis and MacLean (2010) and Lusardi et al (2010) state that the financial education can also increase people business performance.

The role of parents in financial education are expected not only to provide the theories but also to give examples on how to manage the money wisely. Children who are given good financial education tend to have good financial knowledge and high level of financial literacy.

\section{Literature Review and Hypothesis Development Parent's Motivation on Financial Literacy}

Parents' motivation is important for financial literacy. A parent can be a good example for their children in terms of saving for pension (Garg \& Singh, 2018). Lusardi et al (2010) found that education is the predictor for financial literacy. Ansong and Gyensare (2012) found that there are effects of financial literacy education by the respondent. Cole et al. (2008) suggested that education level in the society affects on financial literacy level. According to Santrock (2008), parents with higher education levels will be more likely to believe that their involvement in children's education is important. There will be increasingly higher in financial literacy. There is a high correlation between a parent's motivation and parent's experiences in financial literacy (Firmansyah, 2014). Therefore, from the above argument the study proposes the following hypothesis:

\section{H1: There is a positive effect of parent's motivation on financial literacy}

\section{Parents' Experience on Financial Literacy}

Financial problems are the challenges that need to be faced by everyone. Economic decline and lack of financial ability can impact family life. Young adults require an element of science and skills of 
finance for personal financial decisions. They get experience from their parents. Jorgensen (2010) suggest that the model of testing the influence of parent's activities who financially literate in the financial literacy of young adults. This study gives an insight into what is felt about the influence of parents on the financial socialization of their child.

Sabri et al (2010) investigate the impact of personality and family background on the financial literacy of students in Malaysia. The consumers' experience in childhood with his parents. Research has been conducted discussing the finances of the family where parents have a positive relationship with financial literacy. Students who have never had experience to discuss finances with their parent has low financial knowledge. Converse students who have experience discussing finances issues with parents and family are positively related to the best financial science than those who never had experience at all. Gudmonson and Danes (2001), Otto, (2013) and OECD Economic Cooperation and Development (2017) describe how frequently people discuss money matters with parents and friends. Parents can help the children to develop financial viability and well-being. Parents can transmit skill, knowledge, through their examples as role models as well as direct teaching. Parents are more just a source of advice. Attitude, behavior and discussing financial matters with their children will have a good financial impact. Discussing financial issues with parents more often is associated with a higher score of financial literacy. The following hypothesis:

\section{H2: There is a positive effect of parents' experience on financial literacy}

\section{Parent's Motivation on Business Performance}

The level of financial literacy in the family affects capacity assets, fulfillment and funding of higher education and retirement. Good literacy among SMEs owners can help in achieving its business objectives, namely good business performance (Aribawa, 2016). According to Deshpande (2013), the achievement motivation in the context of business entrepreneurs refers to the effect of the founders' achievement motivation on business performance; to test whether its influence consistent throughout the United States and Japan. Achievement motivation is disposition to motivate individuals to face challenges in achieving success. Motivation makes individuals have ideals and dreams that can be reached and lead to good performance. According to Collins et al. (2004), the impact of individual and group performance motivations is the success of obtaining funding motivate achievements take into consideration financial achievements and rewards and they share a sense of responsibility for good performance results. The following hypothesis is as follows:

\section{H3: There is a positive effect of parent's motivation on business performance.}

\section{Parent's Experience on Business Performance}

The financial experience of learning is through observation, positive or negative reinforcement, practice and participation, and instruction by parents (Lachance \& Choquette, 2004). Influential parents experience give positive effects on business performance. Parent's as role models through direct teaching and gives direct experience about money and financial product for their children. The parents give financial skills to the children by giving them pocket money and asking them to manage by themselves. It will increase their skills to manage their finances. As they grew and worked in the small-medium enterprise sector, they enhance their financial skills and give effect to business performance (Gudmonson and Danes, 2011; Otto, 2013; OECD, 2017). The hypothesis derived as follows: 
INTERNATIONAL JOURNAL OF ACADEMIC RESEARCH IN BUSINESS AND SOCIAL SCIENCES

Vol. 10, No. 7, July, 2020, E-ISSN: 2222-6990 @ 2020 HRMARS

\section{H4: There is a positive effect of parent's experience on business performance}

\section{Financial Literacy and Business Performance}

Financial literacy is the knowledge and ability in organizing personal and business finance. Intelligence and the capabilities of financial management are important aspects of life (Boehnke et al., 2018). Financial literacy may prevent people from financial problem. Financial literacy shows the ability to give information and good reasoned for economic and decisions in their finance (Mandell, 2008; Rosacker \& Rosacker, 2016). As revealed by Vitt et al., (2000), Lusardi et al. (2014) and Berry et al. (2018), financial literacy education is the capability to read, implement and control on financial literacy conditions that influence well-being. Recent empirical works focus on the analysis of financial behavior (Brown et al., 2017; Fernandes et al., 2014; Miller et al., 2015; Kaiser \& Menkhoff, 2016; Grohmann, 2015).

The business owners' financial literacy may effect the performance of their SMEs. Good financial literacy can improve the business management. The structure of the plan work, the existence of sales growth and fixed costs can effectively anticipate production when demand increases. Dahmen and Rodriguez (2014) stated that the required financial literacy level for understanding trade mainly for the preparation of the financial statements to funding his business. For a business owner, it is important to understand financial knowledge to have a better performance of the company. There is a relationship between financial literacy and entrepreneurs' business performance. The relationship logically applies to companies with financial literacy that will be able to strategically identify and respond to changes in the business climate, economy, and finance. The decisions taken will create innovative solutions and directional well to improved business performance and sustainability efforts.

According to Bodvarsson and Walker (2004) and Lyons (2003; 2004), bad financial management can affect performance, mental and physical well-being. Aribawa (2016) and Rahayu and Musdholifah (2017) use structural equation models to analyze data. The results posit that there is a financial literacy influence on the performance and sustainability of SMEs in Central Java. The presence of a good financial literacy expected SMEs will have the ability to make decisions and the right financial management to increase the performance of SMEs. With a high level of financial literacy, the entrepreneur will further optimize its business performance with a better and more cautious operation. It will be easier for business management when employers have good financial knowledge capabilities. The resulting business decision and financial management will lead to the development of SME sector with good financial literacy skills. This leads to the following hypothesis:

H5: There are positive effects of financial literacy on business performance

\section{Financial Literacy as the Mediating Variable on the Relationship Between Parents' Motivation and Experience on Business Performance}

According to Hogan et al (2012), a parent's work experience correlates with financial literacy. Parents with high work experience will affect their children with high knowledge and skill financial literacy. Furthermore, financial literacy influences the performance of a business. This happens because the more often the intensity of a person is faced with financial problems and the financial literacy rate is allocated, will be higher knowledge and ability to finance and better performance of his efforts. It can 
INTERNATIONAL JOURNAL OF ACADEMIC RESEARCH IN BUSINESS AND SOCIAL SCIENCES Vol. 10, No. 7, July, 2020, E-ISSN: 2222-6990 @ 2020 HRMARS

be concluded that parents' work experience is an indirect effect on the performance of the business which is mediated by financial literacy.

A lesson about financial literacy from the family is an important factor in children's basic life education. Teaching children about financial literacy was supposed become one of the important duty of the parents. The family is the first community for children to interact with other people, and also their first source for learning various things, includes their education of financial literacy. The impact of further financial circumstances will not differ with their parent's financial circumstances, and their business performance will be better (Rapih, 2016). This indicates the existence of a strong motivation, instruction, education, and experience of parents will influence the individual's financial literacy which later gives an effect on their business performance. As it is formulated in the following hypothesis:

H6: Financial literacy mediates the relationship between parents' motivation and business performance

H7: Financial literacy mediates the relationship between parents' experience and business performance

\section{Conceptual Model}

Figure 1

Conceptual Model

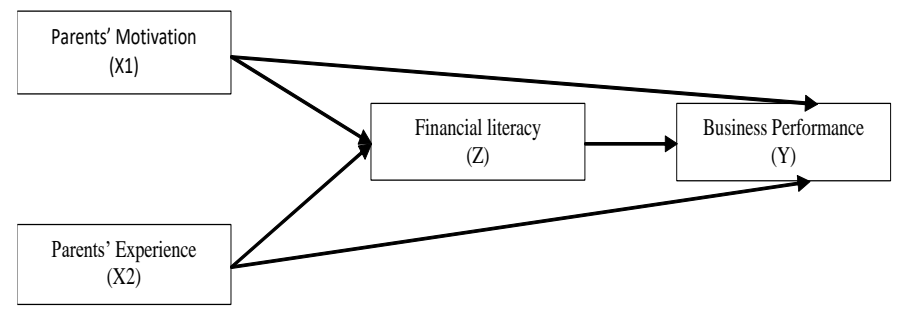

\section{Population and Sample}

The population in this research were small-medium enterprises that are located in Sumatera, Indonesia. The sample were taken from the population. The data were obtained from a questionnaire survey. The questionnaires were disseminated to SMEs owners in Sumatera, Indonesia. The categories under definition of SMEs including micro company and small company industry with one proprietary are included for the purpose of this research. The data was analyzed using a structural equation model (SEM), based on a partial least square (PLS).

The sample was part of the population to be tested. SMEs are engaged in different areas, namely: Aceh Nangroesalam, Sumatera, Utara, Sumatera Barat, Riau, Jambi, Sumatera Selatan, Bengkulu, Lampung, Kepulauan Bangka Belitung dan Kepulauan Riau. According to Sakaran (2018), a minimum sample of 384 respondents is sufficient for 1,000,000 population. 
INTERNATIONAL JOURNAL OF ACADEMIC RESEARCH IN BUSINESS AND SOCIAL SCIENCES

Vol. 10, No. 7, July, 2020, E-ISSN: 2222-6990 @ 2020 HRMARS

\section{Measurements}

Previous studies on business performance, financial literacy, parents' motivation and experience have used the questionnaires for data collection and the studies are presented in Table 1.

Table 1

Research design

\begin{tabular}{lll}
\hline \multicolumn{1}{c}{ Variables } & Instruments & \multicolumn{1}{c}{ Measurement } \\
\hline $\begin{array}{l}\text { 1. } \begin{array}{l}\text { Business } \\
\text { performance }\end{array} \\
\text { 2. Financial Literacy }\end{array}$ & Questionnaires & $\begin{array}{l}\text { Pellissier et al., 2004, Aribawa, 2016; Rahayu } \\
\text { and Musdholifah, 2017, Yusitha, 2017. }\end{array}$ \\
$\begin{array}{l}\text { 3. Parent motivation } \\
\text { 4. Parent Experience }\end{array}$ & Questionnaires & $\begin{array}{l}\text { Chen and Volpe 1998, Sabri et al, 2010; } \\
\text { Nababan and Sadalia, 2012; Rahayu and } \\
\text { Musdholifah, 2017, Yusitha, 2017 }\end{array}$ \\
\hline
\end{tabular}

\section{Dependent Variable-Business Performance}

Dependent variables are variables that are affected by the independent variables. In this study, business performance represents the dependent variable. The measurement for business performance for this study was adapted from Pellissier et al. (2004), Aribawa (2016), Rahayu and Musdholifah (2017), and Yusitha (2017). In measuring the business performance, a five-point Likertscale was used. The scale was represented as follow; 1 = strongly disagree, $2=$ disagree, 3 = neutral, $4=$ agree and $5=$ strongly agree. Higher scores indicated good business performance.

\section{Mediating Variable - Financial Literacy}

The financial literacy measurements were based on true or false questions. The numbers of the correct answers were calculated and divided with all the correct answers by the respondents. The answers were then divided into two different groups. The groups were categorized as follows: true = 1 , and false $=0$. The number of the correct answer is calculated and divided with all the correct answers by the respondent. Answers of the respondents then divided into three categories (Nababan \& Sadalia, 2012; Sabri et al., 2010; Aribawa, 2016; Rahayu \& Musdholifah, 2017; \& Yusitha, 2017) namely: group 1 ( $60 \%$ of business owners have low knowledge and ability), Group 2 (60\%-79\% of business owners have the knowledge and ability) and Group 3 (> 80\% of business owners have a high knowledge and ability). For the result of financial literacy meaurement, scale used refers to likert scale, as it also used to other variables in this research. The financial literacy are divided into five groups, group $1=(0 \%-40 \%$ of business owners have very low financial literacy), $2=(40 \%-59 \%$ of business owners have low financial literacy), $3=(60 \%-79 \%$ of business owners have middle financial literacy), $4=(80 \%-99 \%$ of business owners have high financial literacy), $5=$ and $(100 \%$ of business owners have very high financial literacy). 
INTERNATIONAL JOURNAL OF ACADEMIC RESEARCH IN BUSINESS AND SOCIAL SCIENCES

Vol. 10, No. 7, July, 2020, E-ISSN: 2222-6990 @ 2020 HRMARS

\section{Independent variable -Parent Motivation and Parent Experience}

According to Widayati (2012), Rapih (2016), and OECD (2017), parent's motivation and experience are measured using Likert-type measurement 1-5 ( 1 = strongly disagree, 2 = disagree, 3 = neutral, 4= agree and 5 = strongly agree).

\section{Result and Discussion \\ Descriptive}

In this study, the questionnaires were distributed to SMEs owners in Sumatera, Indonesia. The total returned questionnaires were 387. Profiles of the respondents are summarized in Table 2. In this study, it is found that Sumatera Utara district represents the highest respondents with 91 (23.75\%), followed by the Lampung with $61(15.86 \%)$. The result indicates that majority of the respondents hold graduate degree with 177 respondents (45.74\%), followed by senior high school with 134 respondents (34.62\%). In terms of gender, 200 respondents (51.68\%) are men while 187 respondents (48.32\%) are women. Most of the respondents are 20-29 years old with 142 (36.69\%), followed by 40-49 years old 109 (28.17\%). In terms of income, majority of the respondents earn between Rp 500.000 and $\mathrm{Rp} 3.000 .000$ with 155 respondents (40.05\%), followed by Rp 3.100.000 to Rp 7.000.000 with 94 respondents ( $24.29 \%)$.

Table 2

Respondents Profile $(\mathrm{N}=387)$

\begin{tabular}{|c|c|c|c|}
\hline Characteristics & & Frequency & Percentage (\%) \\
\hline \multirow[t]{10}{*}{ Province } & Aceh & 33 & 08.70 \\
\hline & Sumatera Utara & 91 & 23.75 \\
\hline & Sumatera barat & 48 & 11.95 \\
\hline & Riau & 40 & 10.48 \\
\hline & Jambi & 25 & 06.40 \\
\hline & Sumatera Selatan & 51 & 13.26 \\
\hline & Bengkulu & 15 & 04.03 \\
\hline & Lampung & 61 & 15.86 \\
\hline & Kepulauan Bangka Belitung & 11 & 02.57 \\
\hline & Kepulauan Riau & 12 & 03.02 \\
\hline \multirow[t]{6}{*}{ Level of Education } & Yunior High School & 14 & 3.62 \\
\hline & Senior High School & 134 & 34.62 \\
\hline & Diploma & 42 & 10.85 \\
\hline & Graduate & 177 & 45.74 \\
\hline & Master & 18 & 4.65 \\
\hline & Doctorate & 2 & 0.52 \\
\hline \multirow[t]{2}{*}{ Gender } & Men & 200 & 51.68 \\
\hline & Women & 187 & 48.32 \\
\hline \multirow[t]{5}{*}{ Age } & $18-19$ & 19 & 4.91 \\
\hline & $20-29$ & 142 & 36.69 \\
\hline & $30-39$ & 67 & 17.31 \\
\hline & $40-49$ & 109 & 28.17 \\
\hline & $50-60$ & 50 & 12.92 \\
\hline \multirow[t]{5}{*}{ Income } & Rp 500.000 - Rp 3.000 .000 & 155 & 40.05 \\
\hline & Rp 3.100.000 - Rp 7.000.000 & 94 & 24.29 \\
\hline & Rp 7.100.000 - Rp 10.000.000 & 57 & 14.73 \\
\hline & Rp 10.100.000- Rp 13.000.000 & 45 & 11.63 \\
\hline & $>\operatorname{Rp} 13.000 .000$ & 36 & 9.30 \\
\hline
\end{tabular}


INTERNATIONAL JOURNAL OF ACADEMIC RESEARCH IN BUSINESS AND SOCIAL SCIENCES Vol. 10, No. 7, July, 2020, E-ISSN: 2222-6990 @ 2020 HRMARS

Table 3 presents the descriptive statistics for parents' motivation, parents' experience, business performance and financial literacy. With regards to parents' motivation, the result shows that the item "My parents motivates and instill financial literacy since early childhood" is rated the highest with a mean of 4.196. Furthermore, the result shows high agreement on all of the statements in relation to parents' motivation with a mean value in the range between 4.072 and 4.196.

Parent's experience provide the descriptive statistic result on parents' experience. The result show the item "parental experience to be my role model in my business" rated the highest, with the mean of 4.305. The statement "I often discuss with parents the use of money" rated as the second higest with the mean of 4.276. Meanwhile, "my family is the first place where I learn financial literacy" rated the lowest with the mean of 3.842. The result of business performance show the item "I have the ability to anticipate sum of production when demand increases" rated the highest, with the mean of 4.075. The statement "the existence of sales growth for my business" rated as the second higest with the mean of 4.028. Mean while, the item "My business creates profitability every year" rated the lowest with the mean of 3.845. The result for financial literacy shows the mean value is between 0.26 and 0.57 with range scale of 0 and 1. 
INTERNATIONAL JOURNAL OF ACADEMIC RESEARCH IN BUSINESS AND SOCIAL SCIENCES

Vol. 10, No. 7, July, 2020, E-ISSN: 2222-6990 @ 2020 HRMARS

Table 3

Descriptive Statistics for Parents' Motivation, Parents' Experience, Financial Literacy and Business Performance $(\mathrm{N}=387)$

\begin{tabular}{|c|c|c|c|}
\hline Variables & Mean & SD & Range \\
\hline Parent motivation & & & $1-5$ \\
\hline Parents motivate me to work in family's business. & 4.155 & 0.769 & \\
\hline $\begin{array}{l}\text { My parent motivates financial education the family } \\
\text { members }\end{array}$ & 4.109 & 0.945 & \\
\hline $\begin{array}{l}\text { My parent plays an important role in the financial } \\
\text { socialization process of their children. }\end{array}$ & 4.072 & 0.877 & \\
\hline $\begin{array}{r}\text { My parent motivates and instill financial literacy since } \\
\text { early childhood. }\end{array}$ & 4.196 & 0.864 & \\
\hline $\begin{array}{r}\text { My parent involves their children in financial decision } \\
\text { making. }\end{array}$ & 4.183 & 0.826 & \\
\hline
\end{tabular}

Parent experience

My family is the first place where I learn financial literacy

Parental experience to be my role model in my business

I often discuss with parents the use of money

I learned to manage my money from my parents

My parent has high financial experience.

I understand the difference between needs and desires

from my parent.

Financial literacy

I overspend to buy daily necessities.

I am only concerned about the knowledge of net asset

Credit card holder can spend without limit.

Buying insurance is the best investment.

All types of investments are profitable.

I can borrow to invest.

Business Performance

My business creates profitability every year

The existence of sales growth for my business.

I have the ability to anticipate sum of production when

demand increases.
$1-5$

$3.842 \quad 0.995$

$4.305 \quad 0.810$

$4.276 \quad 0.888$

$4.039 \quad 0.932$

$4.176 \quad 0.863$

$4.044 \quad 0.907$
1 and 0

$0.35 \quad 0.48$

$0.26 \quad 0,44$

$0.30 \quad 0.46$

$0.56 \quad 0.50$

$0.43 \quad 0.49$

$0.57 \quad 049$

Figure 2 show the result of PLS Allgorithm; parents' motivation, parents' experience, financial literacy and business performance. The validity test indicates that all questionnaire items are valid with factor loading above 0.5 . The results are shown in figure 2 : 
INTERNATIONAL JOURNAL OF ACADEMIC RESEARCH IN BUSINESS AND SOCIAL SCIENCES Vol. 10, No. 7, July, 2020, E-ISSN: 2222-6990 @ 2020 HRMARS

Figure 2

Validity test

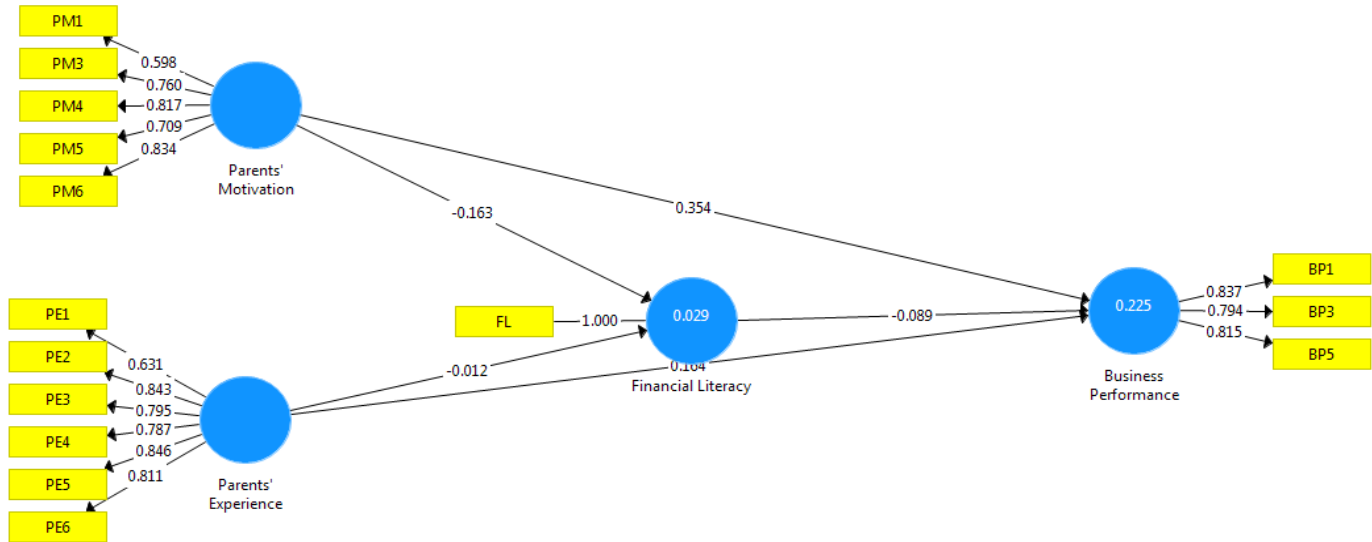

Table 4 presents the croanbach's alpha values for business performance, parents' motivation and parents experience. All of the constructs are reliable with cronbach's alpha above 0.7 , as it is stated by Sekaran, (2018). The financial literacy does not test the validity and reliability because the answer is true or false.

Table 4

Croanbach alpha

\begin{tabular}{lcc}
\hline Constuct & Number of question & Croanbach's alpha \\
\hline Business Performance (BP) & 4 & 0.762 \\
Parents' Motivation (PM) & 5 & 0.818 \\
Parents' Experience (PE) & 6 & 0.901 \\
\hline
\end{tabular}

Figure 3 shows the bootstrapping regression SEM PLS results of parents' motivation, parents' experience, financial literacy and business performance:

Figure 3

Regress SEM PLS

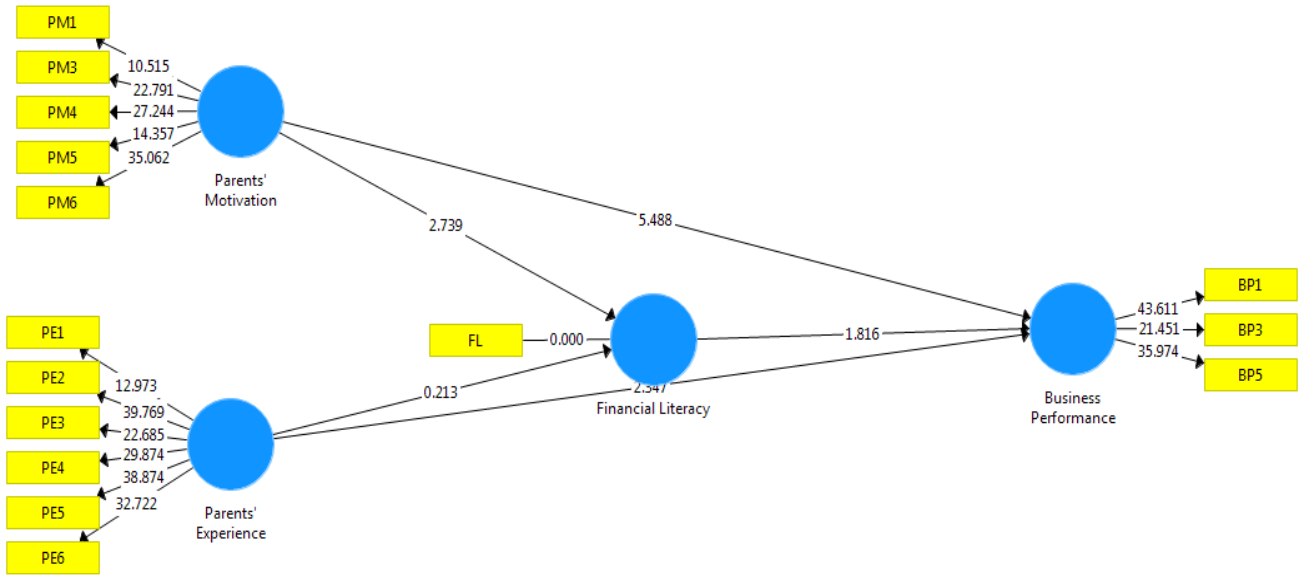


INTERNATIONAL JOURNAL OF ACADEMIC RESEARCH IN BUSINESS AND SOCIAL SCIENCES Vol. 10, No. 7, July, 2020, E-ISSN: 2222-6990 @ 2020 HRMARS

\section{Result of Model 1 (Hypothesis 1 to Hypothesis 2)}

The equation model 1 summarizes the analysis of the parents' motivation, parents'experience and financial literacy regression models. The objective of model 2 is to investigate the relationship between parents' motivation, parents' experience and financial literacy towards business performance. Two independent variables are included in model 2. Business performance is the dependent variable, and parents' motivation, parents' experience and financial literacy represent the independent variable. Model 2 is presented below, followed by the list of variables with the definitions.

Two independent variables are included in model 1. Financial literacy is the dependent variable, The family motivation and family experience are the independent variables. Model 1 is presented below, followed by the list of variables with the definitions.

Model 1: $F L=b_{0}+B_{1} P M+B_{2} P E$

Where;

FL Financial Literacy

b0 Regression coefficient for intercept

$\mathrm{Bi} \quad$ Regression coefficient associated with indenpendent variabel X1

PM Parents' Motivation

PE Parents' Experience

Table 5

Regression Model Summary Statistics

\begin{tabular}{lclc}
\hline Predictors & t-statistics & P Value & VIF \\
\hline Parent motivation & 2.739 & $0.006^{* * *}$ & 1.245 \\
Parent experience & 0.213 & 0.213 & 1.245 \\
& & & \\
R square $\left(\mathrm{R}^{2}\right)$ & 0.029 & & \\
Adjusted R-squared & 0.024 & & \\
\hline
\end{tabular}

a. Dependent Variable: financial literacy

$* * *, * *, *$ indicates regression analysis is statistically significant at $1 \%, 5 \%, 10 \%$ respectively

The results in Table 5 show that parent's motivation has significant relationship to financial literacy. The coefficient of family motivation is significant at $1 \%$ level of significance. Meanwhile parent's experience is not related to financial literacy.

\section{Result of Model 2 (Hypothesis 3 to Hypothesis 4)}

The objective of model 2 is to investigate the relationship between parents'motivation and parents' experience on business performance. Two independent variables are included in model 2. Business performance is the dependent variable, meanwhile parents'motivation and parents' experience represent the independent variable. Model 2 is presented below, followed by the list of variables with the definitions.

Model 2: $B P=b_{o}+B_{1} P M+B_{2} P E$

Where;

BP Business Performance 
INTERNATIONAL JOURNAL OF ACADEMIC RESEARCH IN BUSINESS AND SOCIAL SCIENCES

Vol. 10, No. 7, July, 2020, E-ISSN: 2222-6990 @ 2020 HRMARS

b0 Regression coefficient for intercept

$\mathrm{Bi} \quad$ Regression coefficient associated with indenpendent variabel X1

PM Parents' Motivation

PE Parents' Experience

Table 6

Regression Model Summary Statistics

\begin{tabular}{lccc}
\hline Predictors & t-statistics & P Value & VIF \\
\hline Parent motivation & 5.488 & $0.000^{* * *}$ & 1.245 \\
Parent experience & 2.347 & $0.019^{* *}$ & 1.273 \\
Financial literacy & 1.816 & $0.070^{*}$ & 1.029 \\
& & & \\
R square $\left(\mathrm{R}^{2}\right)$ & 0.225 & & \\
Adjusted R-squared & 0.219 & & \\
\hline
\end{tabular}

a. Dependent Variable: Business Performance

$* * *, * *, *$ indicates regression analysis is statistically significant at $1 \%, 5 \%, 10 \%$ respectively

The results in Table 6 show that parent's motivation has significant relationship to business performance. The coefficient of parents' motivation is significant at $1 \%$ level of significance. In addition, parent's experience related to financial literacy at $5 \%$ level of significance and financial literacy is positively related to business performance at $10 \%$ level of significance.

\section{Result of Model 3, Mediating effect (Hypothesis 6 to Hypothesis 7)}

As indicated by Baron and Kenny (1986), mediation regression analysis is performed in three steps. First, the mediator variable is regressed together with the independent variable. The independent variables are assumed to influence the mediator variable, therefore, there must be a significant relationship between them. Second, the dependent variable is regressed together with the independent variables. Third, the dependent variable is regressed together with both the independent and mediator variables. In all three steps, the result of the relationship between independent variables and dependent variable need to be significant. The significant relationships are to prove the mediation effect on the relationship between the indenpendent variables an the dependent variables.

The equation model 3 summarizes the analysis of the mediation effect of financial literacy between parents'motivation and parents' experience on business performance. The objective of model 3 is to investigate the relationship between parents'motivation and parents' experience on business performance and financial literacy as mediating variable.

In the first step of the mediation regression analysis, financial literacy is regressed on parents' motivation and parents' experience. The step is similar as model 1. In the second step, business performance is regressed on parents' motivation and parents' experience. In the third step, business performance is regressed on parents' motivation and parents' experience towards financial literacy. 
INTERNATIONAL JOURNAL OF ACADEMIC RESEARCH IN BUSINESS AND SOCIAL SCIENCES

Vol. 10, No. 7, July, 2020, E-ISSN: 2222-6990 @ 2020 HRMARS

Three independent variables are included in this step. The model is presented below, followed by the list of variables with the definitions.

Step 3: Model 2: $B P=b_{o}+B_{1} P M+B_{2} P E+B_{3} F L$

Where;

BP Business Performance

b0 Regression coefficient for intercept

$\mathrm{Bi} \quad$ Regression coefficient associated with indenpendent variabel X1

PM Parents' Motivation

PE Parents' Experience

FL Financial Literacy

Table 7

Step 3 Model Summary Statistics of financial literacy mediates between parent's motivation and parents' experience on business performance.

\begin{tabular}{|c|c|c|c|}
\hline Variable & & Model 3 (BP) & \\
\hline $\begin{array}{l}\text { Parents' } \\
\text { motivation }\end{array}$ & -> Financial literacy & $\begin{array}{l}\text {-> business } \\
\text { performance. }\end{array}$ & 0.854 \\
\hline $\begin{array}{l}\text { Parents' } \\
\text { experience }\end{array}$ & -> Financial literacy & $\begin{array}{l}->\text { business } \\
\text { performance }\end{array}$ & 0.162 \\
\hline
\end{tabular}

The results in table 7 show that financial literacy has no mediation effect between parents' motivation and experience towards business performance.

\section{Discussion}

This study seeks to determine the factors that influence business performance and financial literacy. An analysis on 387 respondents in Sumatera Barat generated interesting results. The results show that parent's motivation influences financial literacy but parents' experience has no effect on financial literacy. Futhermore, parents motivation, parents' experience and financial literacy influence business performance. With regards to mediation analysis, financial literacy has no mediation effects between parents' motivation and experience toward business performance.

The findings show that parents' motivation is essential to increase financial literacy. For SMEs owners, parents' motivation is a key factor to becoming financially literate, and also trained parents who teach personal finance interactively through activities at home. Parent's motivation affect their children financial literacy. Parents who give the financial education are expected to give significant contribution to the development of children's finance knowledge. Parents are also expected to give their children's motivation of how to explicitly allocate finance wisely. The level of financial literacy is determined by parents' roles and motivation in providing support in the form of financial education. Through parents' motivation, children are brought to the better desired value system or attitude of life. Parents indirectly has brought children to certain views and habits. Parents have an important role in finance motivation for their children. They capture financial socialization by measuring and relating to the actions of parents in fostering the children's financial independence 
INTERNATIONAL JOURNAL OF ACADEMIC RESEARCH IN BUSINESS AND SOCIAL SCIENCES Vol. 10, No. 7, July, 2020, E-ISSN: 2222-6990 @ 2020 HRMARS

(Van Campenhout, 2015). Through teaching norms and financial concepts, their children are given the opportunity to manage their own finances, which in turn their children are able to carry out their own financial decisions (Norvilitis and MacLean, 2010) as well as financial literacy (Lusardi, et al., 2010).

Parents are the most dominant part of the process of socialization of financial issues to the children. Parents teach and motivate their children to act based on the existing values, beliefs, and knowledge in all areas, including those related to financial literacy. Parents are a place for a child to grow in the very first time. The formation of attitude and fostering of any life values in the family are seen as very important issues. Parents teach that socialization process about financial problems. (Jorgensen, 2007; Rapih, 2016) describe the effect of one's environment over the year who then successfully lead to their current position. Attitudes and values about finance come from the home environment. Good parent's patterns one of which by explicitly motivated, taught and demonstrated financial literacy can affect financial literacy from early childhood to adolescence (Clarke et al., 2005). Direct effects of family conversation and maintaining expenditures or giving gifts can increase children's financial literacy and form attitudes and values about money (Allen et al., 2007; Rapih, 2016).

Financial management and motivation by parents are focused on the understanding of the value of money and the cultivation of the attitude, behavior, and ability to regulate money utilization. It's important to have the managing finance skills well, at least the children should be trained, make payments independently upon their extra needs, manage pocket money, do the job-specific homework to get extra pocket money, looking for light work outside the house, donated and invested. Jorgensen (2007) find that students who are financially still supported by their parent's will have higher financial knowledge, attitudes, and value of financial behavior. Cued et al. (2006) state that parents have a necessary function in the process of financial socialization of their children. The involvement of parents in financial decision-making saving habits taught parents, custom donated taught parents, trusting children do payments themselves. Parents do discussions about financial issues, communication learning of financial education. It is the instrumental in the good formation of financial literacy education in a family environment and college environment.

Good parent's patterns explicitly taught and demonstrated the finance concepts for his children. It affect the financial literacy knowledge from early age to adolescence (Clarke et al., 2005). Family direct influence, keep expenditures and gifts can cause an enhancement of financial knowledge, settings, the arrangement of attitudes, values, and behaviors to money (Allen et al., 2007). Inculcate the values of financial literacy to the child in the family sphere, the role of parents becomes very crucial. Lusardi (2010) states that a child would be better given the education, motivation, good financial behavior from parents at home. By involving parents in education and motivation in financial issue, parents will be more active in guiding the financial behavior of their children and it enhances the children financial literacy.

The parent should involve their children in financial decision making. The determination of financial decisions concern with them, such as pocket money, money-saving. Parents rarely involve their children to take the decision. The absence of dialogue spaces between parents and children will cause less critical for them to address all their financial problems. The simplest thing to start is by 
introducing financial literacy education for children that involving them in financial decision making at least on things that are associated with them. Give the child a space dialogue and discussion about the allocation determination of their finances. The existence spaces of dialogue between parents and children in the financial decision making is beneficial to cultivate critical thinking on financial literacy education.

Widayati (2012) and Rapih (2016) posit that to get the skills to manage finances well, children must be trained in terms of saving, make payment independently on their additional needs, manage their pocket money, look for any part-time jobs outside their house, and also donation and investment. Parent's motivation is important. Parent's motivation related to financial literacy. Jorgensen (2007) found that students with financial literacy obtained from their families get higher scores in financial literacy, attitudes, and behaviors. The family is the most dominant place for the children's socialization process in financial issues. The family is the first source to be introduced to children on how they can be a well-managed person. Through family education, parents bring a value system or life attitude for any children. One example is that parents accompany their children to know any financial views and habits. Parents motivate and teach their children how to act by depending on the values motivation related to financial literacy. Cude et. Al (2006) stated that parents play a very important role in the process of socialization of the financing for their children. The family is the most dominant in process socialization. The process of education includes mentally, physically and intellectually in a family environment will be continue from the childhood until adulthood. For example, children observe and follow their parents actions and attitudes.

The study does not find any significant association between parent's experience and financial literacy. The findings show that people who have experienced discussing finance matters with parents and other family members are not related to financial literacy. The parents are able to help the children to develop the financial skills and knowledge through their motivation and as role models as well as direct teaching. Strong parenting practices such as explicitly teaching and demonstrating financial concepts can influence financial literacy from a young age for SMEs, Unfortunately the experience of parents applied to their children did not necessarily increase its financial literacy.

The parents also need to realize when the children are ready to involve in various financial decisions so that they can take advantage of these windows of opportunity with creating purposive learning experiences. The grade of financial literacy defined as a function of the parents to provide support for financial education within the family. Through family education, the children brought a value system or the attitude to life and accompanied. Jorgensen (2007) states that students who report learning well from their parents about managing their money will have higher financial knowledge, attitudes, and behavioral value than students do not learn much about managing finances from parents. The financial education in the family affected by economic education from parents. Parents bring great differences. However greater related parental experience did improve financial literacy, but this study not supported.

The study finds positive significant association between parent's motivation and business performance. Parental motivation is a process that generates an intensity, direction and individual diligence in a group to achieve a goal and performance. Parents motivate someone to get a good 
INTERNATIONAL JOURNAL OF ACADEMIC RESEARCH IN BUSINESS AND SOCIAL SCIENCES

Vol. 10, No. 7, July, 2020, E-ISSN: 2222-6990 @ 2020 HRMARS

business performance. Parent elements are most dominant in motivation. Parents' motivation increase the spirit of SMEs, develop high discipline, improve the creativity and inovative. The parents' motivation directs an entrepreneurial to work successfully, so the wishes and objectives are accomplished. Parental motivation can affect the work outcome. A person who has a high level motivation from parents will get better results in doing business than those with the low level motivation from parents.

This study also finds positive effect of parent experience on business performance. Sabri (2011) posted that someone's childhood life has taught her about financial to have a positive effect on financial literacy. The involvement of parents in financial literacy provides a hang of finance science and experience money management. Parental experience is a thrust for a person to contribute as likely to the success of the business in achieving its objectives and good performance Parents are expected to provide sufficient understanding to his son about financial literacy. Children who are given good financial education tend to have good financial knowledge. With the presence of a good financial education, the literacy rate will affect the child who would ultimately have an effect on business performance conducted. Living together with a large family has an impact on negative financial literacy but consultative decision-making has a positive impact. The effect of living together from the main aspects of Indian family life shows the participation of family members in financial literacy programs to increase family financial decisions appropriately (Agarwall et al, 2015).

The study also find positive significant effects of financial literacy on business performance. Financial literacy is part of basic human needs in achieving good business performance. Financial problems caused by inappropriate financial management. Managing finance has a significant role in determining the success of the SMEs' business performance. Understanding and capabilities of financial management are essence to business finance and business performance. Some researches review financial literacy to improve the well-being of society. The studies are conducted by Lusardi and Mitchell (2008). SMEs are small businesses productive economies conducted by individuals or businesses. Currently, Smash work to get attention guaranteed by Indonesian laws such as business loans with a low-interest rate, easiness in obtaining a business license, business continuity from government agencies, and some other facilities. Currently, financial literacy is also a pertinent subject to governments, financial institutions, education, and media for national and international classes (Opletalová, 2015).

Low financial literacy of the owners of SMEs may cause to low business performances. SMEs are not growing and the economy will decrease. A need for an understanding of financial literacy is indispensable for business, especially for SMEs owners, that their business is considered as one of the factors that support the national economy. Individuals can avoid financial problems and get the right decisions about finances. Good finance determines the priority of necessity. Less financial literacy will greatly influence a person's healthy financial condition. Lack of financial literacy leads to more mistakes in financial decision making and it causes bad business performance. It shows that financial literacy education from families is important, and should be introduced as early as possible to the children. Adult education about financial literacy became a concern in some countries in the world. That is because the awareness correlates between financial management and human wellbeing. In Indonesia, the financial literacy education has started at preliminary schools and it is well 
INTERNATIONAL JOURNAL OF ACADEMIC RESEARCH IN BUSINESS AND SOCIAL SCIENCES Vol. 10, No. 7, July, 2020, E-ISSN: 2222-6990 @ 2020 HRMARS

developed by the Ministry of Education and Culture. The financial literacy education is essential in making financial decision particularly for adults.

The high level of financial literacy will further optimize the business performance better and cautious in operation. If the business owners have good financial knowledge, it will be easier for them in managing its business. This statement is also supported by some previous researches. Aribawa (2016) in his research, stating that if businesses in the SMEs have good financial literacy skills, the business decisions and financial management generated will lead to a growing direction that improves over time. Adamoko et al. (2015) conducted a study in Ghana showed that financial literacy has a positive effect on the company's growth. Increasing financial literacy causes a business person to produce a reliable financial statement. Wise (2013) found that entrepreneurs who produce more frequent and reliable financial statements will have long-term business continuity.

Futhermore, the study finds that financial literacy does not mediate the relationship between parents' motivation and experience towards business performance. According to Mandell (2008), parent's involvement (parents motivation and parents' experience) play a major role in financial education and understanding for their children. Most children learn financial management skills from home. The survey results showed that $58.3 \%$ of the children skills are developed from home, $19.5 \%$ from education in schools, and the $17.6 \%$ from the parents' experience. This is confirmed by a research conducted by Shim (2010). It explains that families and parent's primary socialization agents are essential in the childrens' process of learning. They learn money and development behavior of financial management processes intentionally (through direct participation or observation). In the end, for business owners, they develope the financial literacy skills from young age and it contributes in managing the business effectively.

\section{Conclusion and Recommendation for Future Studies}

To conclude this paper, it was found that there is effect of parent's motivation on financial literacy but parents' experience has no effect on financial literacy. Futhermore, parents' motivation, parents' experience and financial literacy influence business performance partially. Financial literacy has no mediation effects between parents' motivation and experience towards business performance.

For future research, it would be interesting to include other variables such as capital, human resources, and technology in order to enhance the result-in the finance area. The respondents of this study are from Sumatera. In future, it is recommended to include other respondents from different islands in Indonesia.

\section{References}

Adomako, S., Danso, A., Damoah, J. O. (2015). The moderating influence of financial literacy on the relationship between access to finance and firm growth in Ghana. International Journal of Entrepreneurial Finance. 18(1), 43-61.

Agarwal, S., Driscoll, J. C., Laibson, D. I. (2013). Optimal mortgage refinancing: A closed-form solution. J. Money, Credit Banking 45 (4), 591-622 .

Anggraeni, B. D. (2015). Pengaruh tingkat literasi keuangan pemilik usaha terhadap pengelolaan keuangan. Studi Kasus: UMKM Depok. Jurnal Vokasi Indonesia. 3(1), 22-30. 
INTERNATIONAL JOURNAL OF ACADEMIC RESEARCH IN BUSINESS AND SOCIAL SCIENCES

Vol. 10, No. 7, July, 2020, E-ISSN: 2222-6990 @ 2020 HRMARS

Ansong, A., \& Gyensare, M. A. (2012). Determinants of university working-students' financial literacy at the University of Cape Coast, Ghana. International Journal of Business and Management. 7 (9), 126-133.

Allen, M. W., Edwards, R., Hayhoe, C. R., \& Leach, L. (2007). Imagined interactions, family money management patterns and coalitions, and attitudes toward money and credit. Journal of Family and Economic Issues, 28(1), 3-22.

Aribawa, D. (2016). Pengaruh literasi keuangan terhadap kinerja dan keberlangsungan UMKM di Jawa Tengah, Jurnal Siasat Bisnis, 20(1), 1-13.

Baron, R. M., and Kenny, D. A. (1986). The moderator-mediator variable distinction in social psychological research: Conceptual, strategic, and statistical considerations. Journal of Personality and Social Psychology. 51(6), 1173.

Berry, J., Karlan, D., Pradhan, M. (2018). The impact of financial education for youth in Ghana. World Development. 102, 71-89.

Boehnke, M., Pokharel, S., Nyberg, E., \& Clark, T. (2018). Financial education for radiology residents: Significant improvement in measured financial literacy after a targeted intervention. Journal of the American College of Radiology. 15(1), 97-99.

Brown, M., Henchoz, C., \& Spycher, T. (2017). Culture and financial literacy. Working Papers on Finance. 03, Swiss Institute Of Banking And Finance.1-53.

Clarke, M. D., Heaton, M. B., Israelsen, C. L., \& Eggett, D. L. (2005). The acquisition of family financial roles and responsibilities. Family and Consumer Sciences Research Journal, 33(4), 321-340.

Cole, Shawn, Sampson, T., and Zia, B. (2008). Money or knowledge? What drives the demand for financial services in developing countries? Harvard Business School Working Paper. 09,117.

Collins, C. J., Hanges, P. J., and Locke, E. A. (2004). The relationship of achievement motivation to entrepreneurial behavior: A meta-analysis. Human Performance. 17(1), 95-117.

Cude, Brenda, Frances Lawrence, Angela Lyons, Kaci Metzger, Emily LeJeune, Loren Marks, and Krisanna Machtmes. (2006). College students and financial literacy: What they know and what we need to learn. Proceedings of the Eastern Family Economics and Resource Management Association. 102-109.

Dahmen, P., dan Rodriguez, E. (2014). Financial literacy and the success of small businesses: An observation from a small business development center. International Journal of Numeracy. 7, 1-12.

Deshpande, R. (2013). Achievement motivation, Strategic orientations and business performance in entrepreneurial firms how different are Japanese and American founders? International Marketing Review. 3(3), 231-252.

Desiyanti, R. (2016). Literasi dan inklusi keuangan serta indeks utilitas UMKM di Padang. Bisman Jurnal Bisnis dan Manajemen. 2(2), 122-134.

Enterprise Survey.(2015). Indonesia, 2015 World Bank.

Fernandes, D., Lynch, Jr. J. G., and Netemeyer, R. G. (2014). Financial literacy, financial education, and downstream financial behaviors. Management Science. 60(8), 1861- 1883.

Firmansyah, D. (2014). The influence of family backgrounds toward student saving behavior: A survey of college students in Jabodetabek. International Journal of Scientific and Research Publication. 1(1), 2250-3153.

Garg, N., Singh, S. (2018). Financial literacy among youth. International Journal of Social Economics, $45(1), 173-186$. 
INTERNATIONAL JOURNAL OF ACADEMIC RESEARCH IN BUSINESS AND SOCIAL SCIENCES

Vol. 10, No. 7, July, 2020, E-ISSN: 2222-6990 @ 2020 HRMARS

Grohmann, A., Kouwenberg, R., \& Menkhoff, L. (2015). Childhood roots of financial literacy. Journal of Economic Psychology. 1(1), 114-133.

Gudmondson, C. G., Danes S. M. (2011). Family financial socialization: Theory and critical review. Journal of family and economic issues. 32 (4), 644-667.

Jorgensen, B. L. (2007). Financial literacy of college students: Parental and peer influences, Thesis.

Kaiser, T., and Menkhoff, L. (2016). Does financial education impact financial behavior, and if so, when? Working Paper

Lachance, M. J., \& Choquette-Bernier, N. (2004). College students' consumer competence: A qualitative exploration. International Journal of Consumer Studies. 28, 433 - 442.

Lusardi, A., Mitchell, O. S. (2008). Planning and financial literacy: How do women fare? American Economic Review, 98 (2), 413-417.

Desiyanti, R., \& Kassim, A. A. M. (2020). Parents' Motivation and Experience on Business Performance: The Mediating Effect of Financial Literacy Among SMEs in Sumatera, Indonesia. International Journal of Academic Research in Business and Social Sciences, 10(7), 28-48.

Mandell, L. \& Klein, S. L. (2007). Motivation and financial literacy. Financial Services Review. 16, 105116.

Miller, M., Reichelstein, J., Salas, C., and Zia, B. (2015). Can you help someone become financially capable? A meta-analysis of the literature. World Bank Research Observer. 30(2), 220-246.

Nababan, D., \& Sadalia, I. (2012). Analisis personal financial literacy dan financial behavior mahasiswa strata I Fakultas Ekonomi Universitas Sumatera Utara. Media Informasi Manajemen. 1(1),1-15.

Norvilitis, J. M., and MacLean, M. G. (2010). The role of parents in college students' financial behaviors and attitudes. Journal of Economic Psychology, 31(1), 55-63.

Novi, Y. A. (2017). Pentingnya literasi keuangan bagi pengelolaan keuangan pribadi, Jurnal Nominal, 6(1), 11-26.

OECD. (2017), Students experience with money and their performance in financial literacy, PSA 2015 Result, Volume IV: Students' financial literacy.

Opletalová, A. (2015). Financial education and financial literacy in the Czech education system. Procedia - Social and Behavioral Sciences. 171, 1176-1184.

Otto, A. (2013). Saving in childhood and adolescence: Insight from developmental, psychology, Economic of education review. 33. 8-18.

Pellissier, R. (2014). Measuring business performance: A case study. p.1-15.

Rahayu, A. P., Musdholifah. (2017). Pengaruh literasi keuangan terhadap kinerja dan keberlanjutan UMKM di kota Surabaya. Jurnal IImu Manajemen. 5 (3) 1-7.

Rapih, S. (2016). Pendidikan literasi keuangan pada anak: mengapa dan bagaimana? Scholaria. 6(2), $14-28$.

Rosacker, K. M., \& Rosacker, R. E. (2016). An exploratory study of financial literacy training for accounting and business majors. International Journal of Management Education. 14(1), 1-7.

Sabri, M. F., \& Gudmunson, C. C. (2012). Financial well-being of malaysian college student. Asian education and development studies (1) 2.

Santrock, J. W. (2008). Psikologi Pendidikan. Jakarta: Prenada Media Group.

Sekaran, U. (2018). Research methods for business: A Skill-building approach, 6th Edition, Wiley.

Van Campenhout, G. (2015). Revaluing the role of parents as financial socialization agents in youth financial literacy programs. Journal of Consumer Affair. 49(1), 186-222. 
INTERNATIONAL JOURNAL OF ACADEMIC RESEARCH IN BUSINESS AND SOCIAL SCIENCES

Vol. 10, No. 7, July, 2020, E-ISSN: 2222-6990 @ 2020 HRMARS

Vitt, L. A., Anderson, C., Kent, J., Lyter, D. M., Siegenthaler, J. K., \& Ward, J. (2000). Personal finance and the rush to competence. Financial Literacy Education in The U.S. Middleburg, VA: Fannie Mae Foundation.

Widayati, I. (2012). Faktor-faktor yang mempengaruhi literasi finansial mahasiswa fakultas ekonomi dan bisnis universitas brawijaya. Jurnal Akuntansi dan Pendidikan. 1(1), 89-98.

Wise, N. (2013). The impact of financial literacy on new venture survival. International Journal of Business and Management, 8(23). 8(23), 30-39. 